See discussions, stats, and author profiles for this publication at: https://www.researchgate.net/publication/263125069

\title{
Public buying decisions: A framework for buyers and small firms
}

Article in International Journal of Public Sector Management · January 2013

DOI: 10.1108/IJPSM-11-2012-0144

CITATIONS

6

3 authors:

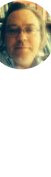

David Mckevitt

Cork University Hospital

19 PUBLICATIONS 132 CITATIONS

SEE PROFILE

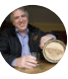

Paul Davis

Dublin City University

68 PUBLICATIONS 200 CITATIONS

SEE PROFILE

Some of the authors of this publication are also working on these related projects:

E-procurement as alternative View project

Project SME involvement in public procurement View project
25 PUbliCATIONS 156 CITATIONS

SEE PROFILE 
IJPSM

27,1

\section{4}

Received 11 November 2012 Revised 6 May 2013

Accepted 14 May 2013

\section{Public buying decisions: a framework for buyers and small firms}

\author{
David Mark McKevitt, Anthony Flynn and Paul Davis \\ Dublin City University, Dublin, Ireland
}

\begin{abstract}
Purpose - The aim of this paper is to explore the factors that influence buyer decision-making in public procurement. The objective is to better understand the processes and conditions that support different supply arrangements, which maximise SME participation.

Design/methodology/approach - The paper uses case study evidence of contract awards across multiple organisational contexts including: a local authority, commercial semi-state, police force, and a tourist agency.

Findings - National policy and the role of procurement exerted mixed effects upon the cases. The procurement processes were broadly similar and included cross-functional teams, consideration of trade-offs and market research.

Research limitations/implications - The paper highlights the transition of public organisations toward strategic procurement including supplier engagement.

Practical implications - This offers buyers a decision support tool that promotes equal opportunities for SME participation, a key goal of EU procurement. The implications for suppliers of each buying decision are also outlined. The concept of practical rationality is used to support the framework.

Originality/value - A normative framework of public procurement decision-making is generated from the cases. Buying complexity and supplier engagement are two conditions that support a $2 \times 2$ decision framework. The framework extends efficient and central-buying decisions to include adapted and balanced decisions. This range offers buyers a decision support tool that promotes equal opportunities for SME participation, a key goal of EU procurement. The implications for suppliers of each buying decision are discussed.
\end{abstract}

Keywords Ireland, Public procurement

Paper type Case study

\section{Introduction}

Scholars and policy makers are increasingly aware of how public procurement may support government objectives. In Ireland, the context of this study, initiatives have been designed to make public procurement consistent with enterprise development and innovation policies. Particular emphasis is placed on creating a "level playing field" on which small and medium enterprises (SME) compete for a share of the estimated $€ 14$ billion public contract market. However there are gaps between the potential and actual impact of procurement policy to date (Murray, 2001; Preuss, 2007, 2009). The interaction of context and the process of public procurement may explain this gap.

EU procurement legislation dictates that efforts to increase SME participation are

International Journal of Public Sector Management

Vol. 27 No. 1, 2014

pp. 94-106

(C) Emerald Group Publishing Limited 0951-3558

DOI 10.1108/IJPSM-11-2012-0144 limited to equality of opportunity rather than equality of outcomes. A consequence is a "conformance-performance" tension where regulations may conflict with performance aspects like securing value for money (Schapper et al., 2006; Cabras, 2011). The extent to 
which public policy is enacted is, ultimately, dependent on public sector organisations. Specifically it is buyer decision making, which influences the extent to which procurement policy translates into practice (Beyer and Trice, 1982). Buyers pursuing strategic procurement often rationalise the supply base and make greater use of centralised framework agreements. A consequence of this decision is public hostility particularly on the part of SMEs. Small firms can, of course, continue to chase "low value" spend. We argue that "central" and "efficient" buying decisions do little to reconcile rational and normative aspects of public procurement. The aim of the research is thus to explore a range of buying options through an in-depth study of multiple contract awards. To this end and using case study research we propose a framework to guide buyer decision-making that maximises SME participation in public procurement.

First a review of the context of $\mathrm{EU}$ and national procurement policy is given. This highlights competing pressures that shape the context of public buying decisions including national policy and the role of procurement. We then examine the assumptions of portfolio models, which guide decision processes in procurement. The methods section justifies the selection of contract awards as the unit of analysis, which is investigated using a combination of primary and secondary sources of evidence. Finally we discuss our findings and the implications of the research for buyers and small firms.

\section{Literature review}

\subsection{Policy environment}

The remit of contemporary public procurement includes meeting traditional goals of cost and value to wider economic, social, environmental and ethical concerns (Arrowsmith, 1995; McCrudden, 2004; Snider and Rendon, 2008). As such it is reasonable to describe public procurement as multi-dimensional in character (Thai, 2001). Scholars refer to the willingness and ability to respond to the policy environment as normative procurement practice (Lloyd and McCue, 2004). The broadening scope of public procurement or what for some is "mission creep" has also raised concerns, however (Erridge and Mcllroy, 2002). One suggestion is for a concept of "public value" to take centre stage in procurement practice (Erridge, 2007; Loader, 2007). Others are less sanguine about the "uneasy mixture" of procurement policies wherein cost efficiencies compete with social policy objectives (Pickernell et al., 2011). To help small firms participate on a "level playing field" a suite of measures was embodied in Circular 10:10 (Department of Finance, 2010) including: reduction in the threshold for the open advertising of contracts from $€ 50,000$ to $€ 25,000$, ensuring financial and insurance capacity criteria are proportionate to the value of the contract, and breaking contracts into lots where practical. Collectively, these attempts seek to make public markets more accessible to SMEs by removing the most commonly identified barriers that inhibit their participation.

\subsection{Public buying process}

The structure and organisation of procurement is key to achieving organisational and policy outcomes. Various stage gate models attempt to trace the contribution of procurement within organisations (Reck and Long, 1988; Cammish and Keough, 1991; Syson, 1992; Murray, 2004). It is generally accepted that clerical purchasing wherein "anyone and everyone" is involved is inferior to strategic procurement, where there is consistency between corporate and procurement strategies (Carr and Smeltzer, 1997).

\section{Public buying decisions}

95 
IJPSM

27,1

96

This alignment is supported by processes including cross-functional teams, market research and consideration of trade-offs (Rajagopal and Bernard, 1993; Harland et al., 1999; Burt et al., 2004). Strategic procurement is characterised as rationalistic and developmental (Hakansson and Gadde, 2010). In either case portfolio models are used to guide buyer decision-making processes such as diversify, exploit or partner with suppliers (Kraljic, 1983). It is difficult, however, to reconcile the normative potential of public procurement with rational theoretical frameworks such as Kraljic. These assume that buyer power drives decision-making (see also Caniëls and Gelderman, 2005). Moreover public procurement emphasises policy objectives (e.g. value for money) rather than profit and, processes of buyer decision-making may be driven by procedural constraints such as de minimus thresholds. For example 80 per cent of EU tenders are "low value procurement" (European Commission, 2011; Telles, 2012). Such procurement corresponds to a "straight re-buy" (Figure 1) and the buying task must be efficient, e.g. soliciting quotations. On the other hand framework agreements driven by regional and central government see suppliers "leveraged" via centralised negotiation and contracting. This constitutes a "modified re-buy" (Figure 1), where buyers pool requirements and suppliers adapt to the new circumstance. Therefore all buying decisions exist on a continuum of complexity.

Taken together, efficient and centralised buying polarizes SME participation. The current literature lacks a framework that classifies a range of public buying decisions. This gap suggests the rhetoric of normative public procurement has outpaced empirical evidence of such practices. There is a need to understand buying decisions on a continuum of complexity and for greater clarity of the factors that influence those decisions. The research questions that the paper sought to investigate are:

(1) What factors influence buyer decision-making in public procurement?

(2) How does support for SMEs require different processes and conditions?

\section{Methods}

Given the exploratory nature of the research questions a case study design was chosen. The research was designed using a multiple case study (Eisenhardt, 1991), with the "case" defined, as a contract award. Purposive sampling was used to select cases and four cases were sufficient to fill theoretical categories (Yin, 2008). For example it was critical that our cases represented the buying continuum (Figure 1) rather than the public sector population. Two criteria were used to select research sites, organisations were nominated to National Procurement Awards (www.procurement awards.ie) and organisations exhibited a variation in context. Once cases were selected and initial pilots completed a qualitative research strategy was pursued. Data was first gathered from procurement directors and then from procurement teams. This gave the researchers sufficient cognitive access (Saunders et al., 2009) to conduct a longitudinal study as well as to satisfy our requests for referrals to suppliers.

Figure 1. Buying decision continuum

\begin{tabular}{|l|c|c|c|}
\hline & Straight & Modified & New \\
\hline Buyer task & Reorder & Modify & Change \\
Supplier task & Supply & Adapt & Innovate \\
Uncertainty & Low & Medium & High \\
\hline
\end{tabular}

Source: Adapted from van Weele (2009, p. 32) 
Primary data consisted of semi-structured interviews, which we conducted with directors, buyers and suppliers for each of the four cases. Secondary data included websites, Corporate Procurement Plans (where available), requests for proposals (RFP) documents and supplier bid documents. Secondary data provided an analytic complement to interviews. The cases consist of two lot-based contracts, 1 single party framework agreement and 1 multiparty framework agreement. The cases represent a range of buying complexity (Figure 1) with a focus on straight to modified buying decisions. Table I is a case summary table, which includes for each case the relationship between organisation and procurement strategies. Whilst each organisation has value for money as procurement objective, one organisation, Dublin Airport Authority (DAA) has strategic relationships with suppliers and another Kilkenny County Council (KLA) sustainability.

\section{Results}

\subsection{Lots-based contracts}

The decision to split large requirements into smaller lots constituted two cases. An Garda Siochána is the Police Service in the Republic of Ireland and Dublin Airport Authority is the State's airport management Authority. In the case of the police force the provision of meals for detainees was previously undertaken at the discretion of each district. Few if any formal contract arrangements were in place. Following training needs analysis across the DAA the Learning and Development team sought to tender for all three airports. Procurement presented a choice of either engaging a "one solution provider" or to seek a range of smaller training providers to supply one or more of 16 core skills programmes.

\subsection{Single party framework agreement}

Fáilte Ireland is the State's the tourism development authority, which provides services to develop and sustain Ireland as a tourism destination. A localisation project required technical, marketing and language translation expertise. Given the discrete skills required to fulfil the project the buyer decided to use a single party framework using the open tender procedure.

\subsection{Multiparty framework agreement}

Kilkenny Local Authority (KLA) is one of 34 local authorities throughout Ireland. As part of its service remit, KLA maintains 20 water supply schemes and 35 wastewater schemes. A decision was needed to either opt for a "winner takes all" approach or, alternatively, apportion the contract to several contractors as part of a multi-party framework agreement. It was decided that works would be allocated between suppliers on a 35-25-20-20-percentage split. Next a within case analysis of policy and the role of procurement is presented.

\subsection{Context-policy and role procurement}

The role of policy did not influence all contracts in the same way. For example the police and KLA chose the lots-based approach based on policy (Circular 10:10). However in both cases policy was necessary but not a sufficient condition. Procurement was also actively questioning the status quo and seeking to contribute to

\section{Public buying decisions}


IJPSM

27,1

98

Table I.

Case summary table

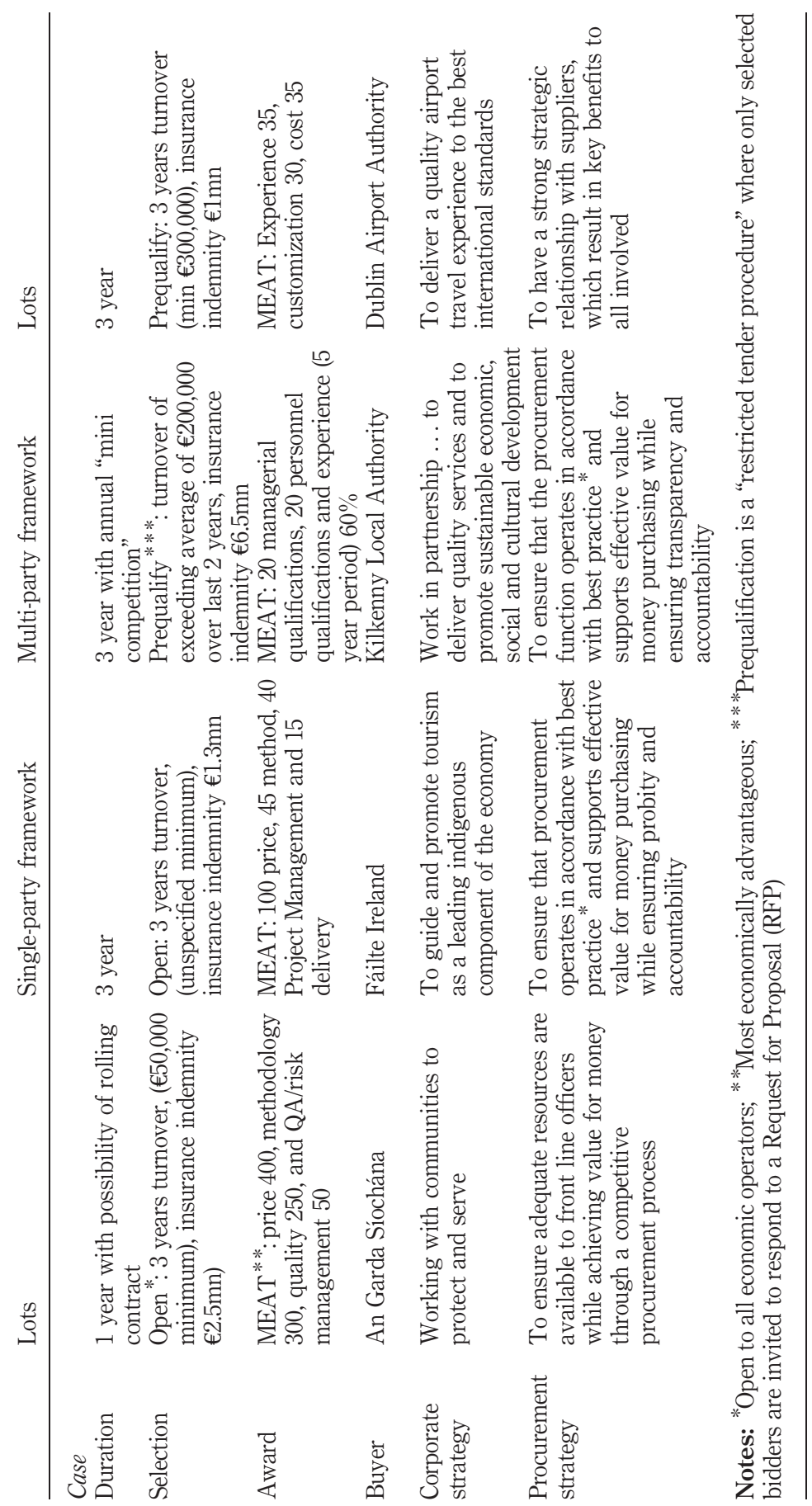


organisational goals. The respective procurement divisions in both organisations aspired to move from operational to strategic procurement:

The main focus of current procurement activity is based on EU compliance and daily operational purchasing, rather than strategic sourcing and planning. [Procurement] should be seen as providing a strategic support role and not simply as one of compliance (KLA, Corporate Procurement Plan, 2008-11, p. 6, emphasis added).

Procurement should be moving to a more strategic footing to drive procurement decisions and practices in accordance with a proper understanding of An Garda Síochána's strategic requirements (AGS, Corporate Procurement Plan, 2010-12, p. 31).

As a commercial semi-state the DAA operates under the Utilities Directive and is exempt from central government procurement policy including C10:10. DAA's strategy was based on three pillars, compliance, value for money and service. Following a major restructuring of procurement a strategic approach to procurement was supported by a category management structure. The neutral impact of policy was replaced with authentic leadership (see George et al., 2007) including the importance of supporting local business.

In the case of Fáilte Ireland the decision to use a Single Party Framework was consistent with the agency's goal to rationalise project administration. Like the other three organisations procurement was becoming more strategic:

The overriding objective [...] is the introduction of a more strategic approach to procurement with a view to delivering sustainable and measurable improvements in customer service and value for money, while ensuring probity and accountability (FI, Corporate Procurement Plan, 2012-14, p. 4).

In order to support rationalisation and preserve SME participation Fáilte Ireland stipulates that supply consortia are acceptable. Whilst procurement policy exerted mixed effects upon the four cases, the procurement processes were similar.

\subsection{Cross functional teams}

From the outset of the change process a procurement committee assisted the procurement team in the police to design the tender specification, and its subsequent award and management. DAA's relationship with Skillnet[1] made the case for a "lots-based" approach even more persuasive. By using small suppliers listed with Skillnet, DAA was eligible for a discount on the cost of services. In the evaluation stage as in all stages a cross-functional group comprising of Procurement and Learning and Development team assumed control of the evaluation process.

4.5.1 Single party framework. The service nature of Fáilte Ireland support means that procurement campaigns tend to be project-based. A project initiation document (PID) is forwarded for approval to a management committee who then seek advice from procurement as to whether or not the requirement will remain regional or be expanded nationally:

In procurement I'm getting to see strategic documents and what's happening now is "are you aware that there's the same requirement in Galway". The earlier that we're involved the better; if you have an idea in your head go to procurement first (Buyer, Fáilte Ireland).

4.5.2 Multi party framework. Before the KLA framework was publicly advertised analysis of cost and capability factors led to a decision to continue with the policy of

\section{Public buying decisions}


IJPSM

27,1

100 using external contractors. In collaboration with Water Services, the Procurement Unit devised documentation for the tender.

There was evidence that the trade-offs vis-à-vis performance-conformance was carefully considered in all four cases.

\subsection{Trade-offs}

4.6.1 Lots-based contracts. The Police procurement team was conscious of the need to minimise barriers that might inhibit small local suppliers from bidding. To this end financial criteria were proportionate to the value of the contract and suppliers with less than three years audited accounts were eligible to apply. It was condition of award (rather than selection) that suppliers issue the DAA with Tax Clearance Certificate and pre-specified insurance cover. While there is a perception that breaking a contract into lots can add to the workload of buyers, the advantages of taking a "lots-based" approach more than offset this effect:

From our point of view we see super value for money and we got the quality service that we need, rather than looking for "one complete solution" we wanted to have the strongest provider for each of those specific courses (Buyer, DAA).

4.6.2 Single party framework. The decision to present the market with a problem to solve succeeded. The winning bidder undertook an extensive search for a suitable partner. The successful consortium was two SMEs:

[it] required research, quite a lot of research to ensure that we were choosing the right company, and we would have to vet the company the same way that Fáilte Ireland would vet us, to ensure that there is consistency in terms of standardisation throughout the businesses [...] (lead supplier).

4.6.3 Multi party frameworks. From the outset, the Procurement Unit was mindful not to "over-spec" the contract and to accommodate small suppliers. It was decided that an essential feature of the new contract was the stipulation that contractors must be able to respond and mobilise on site within two hours of notification by Council. This decision was aimed at reducing water leakage, avoiding environmental damage, and to minimise service disruption to households and local businesses.

\subsection{Supplier engagement}

An emergent factor exhibited by the case organisations was supplier engagement. All of the case organisations attend Meet the Buyer events and the police along with the DAA are currently trialling new products. In making the final decision for the lots approach the procurement team within the police made site visits. Following a short-listing of potential sources of supply and before contract were awarded, DAA requested suppliers to make an oral presentation of their services:

[i]t was very very well run from their side, we enjoyed the experience because sometimes in public sector it can be very formulaic and little opportunity to see if you want to work with these guys (supplier, emphasis added).

In Fáilte Ireland the bidders understanding of the buyers needs was evident in the submission of the bid. Procurement at Fáilte Ireland has recently used "brainstorming days" with potential suppliers. This process proved effective at clarifying opportunities and constraints at the conceptual stage of complex projects. The 
Procurement Director at KLA explained his approach to supplier engagement, which was shared by the other Directors:

[D]on't be afraid to lift the phone, we want to talk to you. Obviously we can't talk to you during a competition process but before we start [...] we have been getting phone calls from people looking for business so it has stimulated interaction and I can think of four to five companies have come to me directly and we're aware of them as a council, they can be re-directed to a service area, I introduce them to the various engineers, and at least they have a chance, a foot in the door.

A summary of the within and cross case analysis is presented in Table II.

The findings demonstrate that public procurement decisions are influenced by the interaction of policy and the role of procurement within the organisation. The four contract awards were in the context of organisations at the rationalisation phase of strategic procurement (Hakansson and Gadde, 2010). The selected cases represented different buying decisions, including lots, single party frameworks and multiparty frameworks.

The decisions are situated between the extremes of the buying continuum (Figure 1). Although the cases represent different theoretical categories the procurement processes were similar. The case studies support careful consideration of trade-offs between efficiency and effectiveness, similar to those found in the literature on sustainable supply management (Pagell and Wu, 2009). For example, splitting of lots was inefficient from the buyer's perspective yet the goal of overall effectiveness was satisfied.

\section{Discussion and conclusion}

A key objective of the paper was to explore the factors that influence buyer decision-making, and to identify the processes and conditions that support SME participation. The findings are now discussed using a typology of efficient, adapted, central and balanced supply arrangements. Our contribution extends buying options from efficient and central to include adapted and balanced. This classification presents a spectrum of opportunities for public buyers to engage with suppliers, whilst being consistent with EU procurement policy. The framework also gives small suppliers an awareness of opportunities for "self-help" (Loader, 2013). The framework proposes that buying complexity and supplier engagement are conditions that support reconciling rationalistic and normative pressures on public buyers. The research contributes to closing the gap between the potential and realised capacity of using procurement to achieve government objectives.

Figure 2 synthesises the findings and generates a normative framework of public buying. The $2 \times 2$ matrix consists of four-buyer decisions and two supporting conditions. The vertical axis is labelled buying complexity, which consists of low complexity in the form of a straight rebuy and moderate to high complexity in the form of a modified rebuy. The horizontal axis illustrates the degree of supplier engagement necessary to facilitate combinations of buying complexity.

\subsection{Efficient}

The simplest form of buying is to solicit three quotes from potential suppliers and award contract to the bidder with the lowest price (A). This quadrant is characterised by a straight rebuy and engagement is a matter of choice rather than design. In the

\section{Public buying decisions}

101 
IJPSM

27,1

102

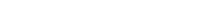

Table II.

Cross case analysis

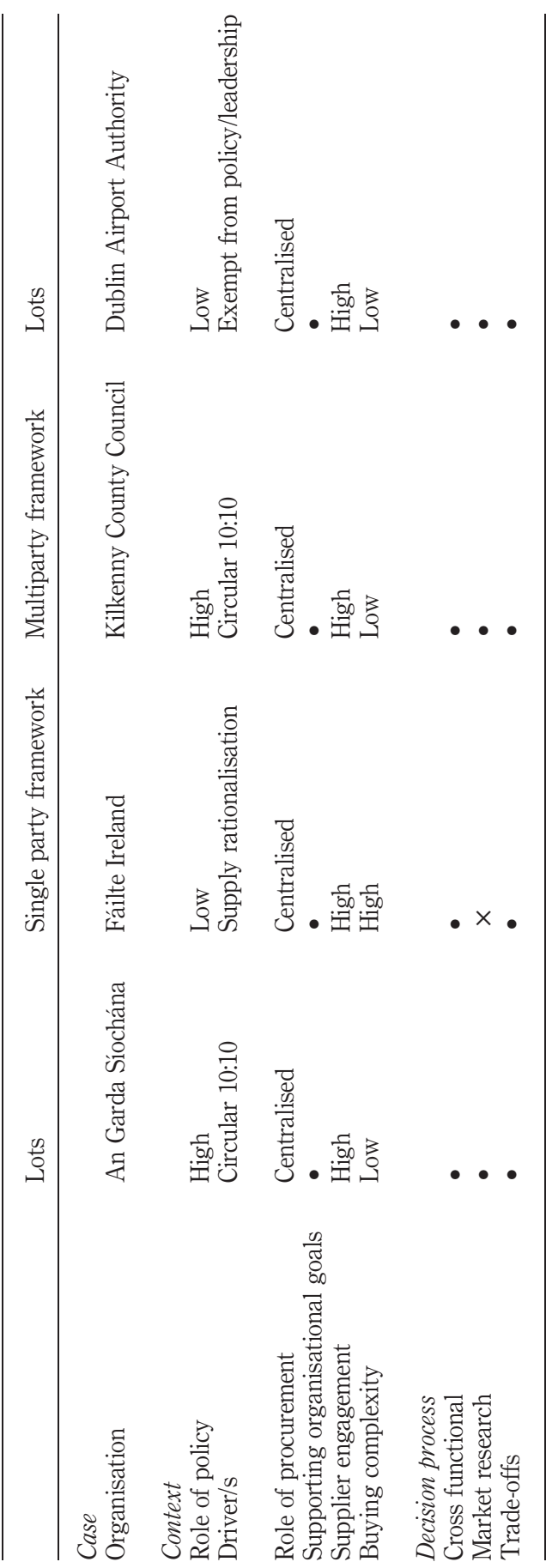




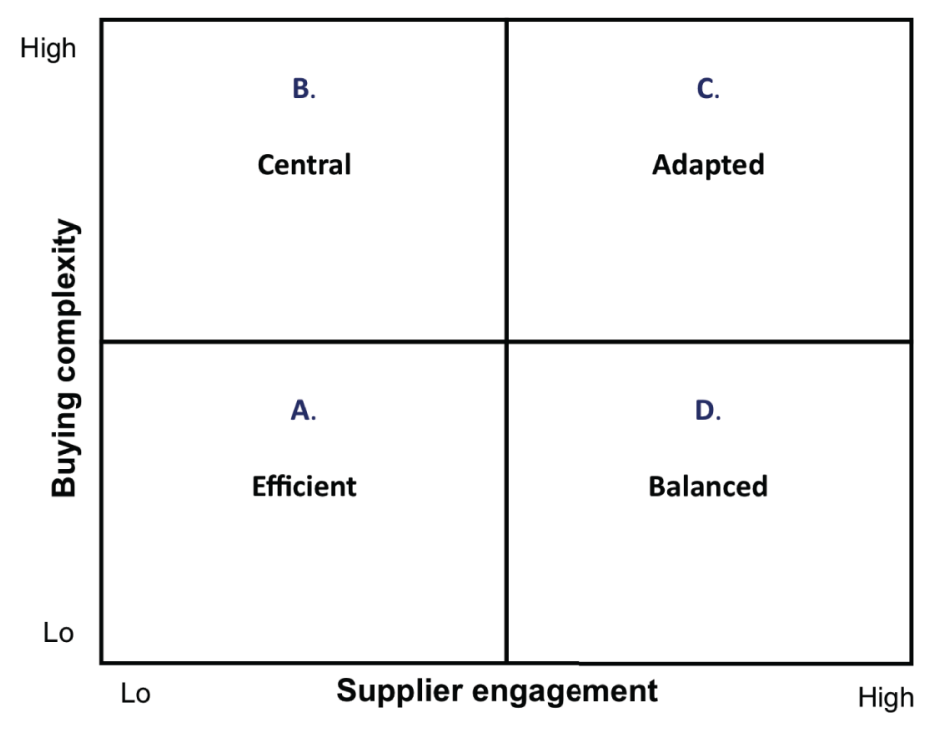

\section{Public buying decisions}

103

Figure 2. Normative public procurement framework

case of the "efficient" procurement the use of lots was supported by supplier engagement, a choice exercised to the fullest by DAA via the negotiated procedure. The decision was aligned to its procurement policy, which is to develop strategic relationships with suppliers and support local suppliers. For SME's in general and microenterprises in particular suppliers need to become adept at pre-tender engagement (McKevitt and Davis, 2013) in order to access "efficient" contracts. The transition from A to B involves aggregation of demand, which sees local buying becoming centre-led.

\subsection{Central}

Buyers may choose to use a centralised framework agreement (B). This constitutes a modified rebuy given the framework typically replaces existing local arrangements. Although complexity is high at the initiation stage relative to spot buying (A), engagement between the supplier/s on the framework and - ultimate- users is likely to be transactional. For buyers to adapt to the centre-led procurement model they need to make decisions based on comparative price variances, volume requirements and existing service levels. Central framework agreements are not currently mandatory for buyers' hence incumbent suppliers can use defensive marketing (Roberts, 2005).

\subsection{Adapted}

For niche requirements adapted processes (C) are necessary. Adapted procurement is typically clear in terms of the outcomes albeit there is less certainty of the process. For "adapted" procurement the use of a single party framework/open tender procedure was in the main a "fishing expedition" sans market research. The stipulation that consortia are a suitable means to respond to Fáilte Ireland tenders coupled with the need to rationalise project administration made this decision appropriate. Where market research has a high cost at the margin buyers are at risk of over or under-specifying requirements. A high level of pre-market engagement thus best supports adapted 
IJPSM

27,1

procurement with potential suppliers. At minimum buyers may issue an open tender and solicit request for proposal (RFP). For SMEs it is important to proactively identify tier 1 suppliers who can act as a lead partner in future consortia. Supply partnerships offer a valuable platform to participate in the public marketplace.

\subsection{Balanced}

Lots can be apportioned in a single contract or rolling framework agreement. A buyer may have legitimate reason to source locally, e.g. performance requirement, say response time. The buyer can still institute competition between suppliers on such a framework. The framework can be local as well as competitive by running "mini tenders". In the case of the multiparty framework, the specification of performance objectives effectively determined "who" could compete and therefore set parameters for local rather than national competition. This decision supported KLA's organisational goal of sustainability and the use of "mini competitions" enhances value for money. The cases of "balanced procurement" demonstrate that legal principles need not distract from the importance of practical rationality (Sanderson, 2006). Practical rationality fuses "what works" with what is "appropriate" on the part of contracting authorities. From a suppliers perspective the cost of bidding for lots is likely to be the same as for a single party framework.

The research has a number of limitations. The cases did not include examples of extremely complex procurement, which involve public organisations supporting R\&D of products or services that do not yet exist (see Uyarra and Flanagan, 2010). Whilst generalisability was not the purpose of the research, the findings are nevertheless embedded in the Irish institutional context. This includes the transposition of EU directives, the influence of non-statutory instruments (see Department of Finance, 2010) and the use of the Utilities Directive to negotiate with potential suppliers.

\section{Note}

1. Skillnets is a state funded, enterprise-led support body dedicated to the promotion and facilitation of training and up skilling as key elements in sustaining Ireland's national competitiveness

\section{References}

Arrowsmith, S. (1995), "Public procurement as an instrument of policy and the impact of market liberalisation”, Law Quarterly Review, Vol. 111 No. 4, pp. 235-284.

Beyer, J.M. and Trice, H.M. (1982), "The utilization process: a conceptual framework and synthesis of empirical findings", Administrative Science Quarterly, Vol. 27 No. 4, pp. 591-622.

Burt, D., Dobler, D. and Starling, S. (2004), World Class Supply Chain - The Key to Supply Chain Management, McGraw-Hill, New York, NY.

Cabras, I. (2011), "Mapping the spatial patterns of public procurement: a case study from a peripheral local authority in Northern England”, International Journal of Public Sector Management, Vol. 24 No. 3, pp. 187-205.

Cammish, R. and Keough, M. (1991), "A strategic role for purchasing”, The McKinsey Quarterly, Vol. 3 No. 3, pp. 22-39. 
Caniëls, M.C.J. and Gelderman, C. (2005), "Purchasing strategies in the Kraljic matrix - a power and dependence perspective", Journal of Purchasing and Supply Management, Vol. 11 Nos 2/3, pp. 141-155.

Carr, A.S. and Smeltzer, L. (1997), "An empirically based operational definition of strategic purchasing”, European Journal of Purchasing and Supply, Vol. 3 No. 4, pp. 199-207.

Department of Finance (2010), "Circular 10/10: Facilitating SME participation in public procurement", Dublin.

Eisenhardt, K.M. (1991), "Better stories and better constructs: the case for rigor and comparative logic", Academy of Management Review, Vol. 16 No. 3, pp. 620-627.

Erridge, A. (2007), "Public procurement, public value and the Northern Ireland unemployment pilot project”, Public Administration, Vol. 85 No. 4, pp. 1023-1043.

Erridge, A. and McIlroy, J. (2002), "Public procurement and supply management strategies", Public Policy and Administration, Vol. 17 No. 1, pp. 52-71.

European Commission (2011), "Public procurement indicators", available at: http://ec.europa.eu/ internal_market/publicprocurement/docs/indicators2010_en.pdf (accessed 6 June 2011).

Hakansson, H. and Gadde, L.E. (2010), Supply Network Strategies, John Wiley \& Sons, Hoboken, NJ.

George, B., Sims, P., McLean, A.N. and Mayer, D. (2007), "Discovering your authentic leadership", Harvard Business Review, Vol. 85 No. 2, pp. 129-138.

Harland, C.M., Lamming, R.C. and Cousins, P.D. (1999), "Developing the concept of supply strategy", International Journal of Operations \& Production Management, Vol. 19 No. 7, pp. 650-674.

Kraljic, P. (1983), "Purchasing must become supply management", Harvard Business Review, Vol. 61 No. 5, pp. 109-117.

Loader, K. (2007), "The challenge of competitive procurement: value for money versus small business support”, Public Money and Management, Vol. 27 No. 5, pp. 307-314.

Loader, K. (2013), "Is public procurement a successful small business support policy? A review of the evidence", Environment and Planning C: Government and Policy, Vol. 31 No. 1, pp. 39-55.

Lloyd, R.E. and McCue, C.P. (2004), "What is public procurement? Definitional problems and implications", International Public Procurement Conference Proceedings, pp. 2-29, available at: www.ippa.org

McCrudden, C. (2004), "Using public procurement to achieve social outcomes", Natural Resources Forum: A United Nations Sustainable Development Journal, Vol. 28 No. 4, pp. 257-267.

McKevitt, D. and Davis, P. (2013), "Micro-enterprises: how they interact with public procurement processes”, International Journal of Public Sector Management, Vol. 26 No. 6, pp. 469-480.

Murray, G.J. (2001), "Improving purchasing's contribution-the purchasing strategy of buying council", International Journal of Public Sector Management, Vol. 14 No. 5, pp. 391-410.

Murray, G.J. (2004), "Even sacred cows have to move: are existing models of Purchasing's strategic development sufficient for local government?", paper presented at 13th IPSERA Conference, April 4-7, University of Catania.

Pagell, M. and Wu, Z. (2009), "Building a more complete theory of sustainable supply chain management using case studies of 10 exemplars", Journal of Supply Chain Management, Vol. 45 No. 2, pp. 37-56.

\section{Public buying decisions}

105 
IJPSM

27,1

Pickernell, D., Kay, A., Packham, G. and Miller, C. (2011), "Competing agendas in public procurement: an empirical analysis of opportunities and limits in the UK for SMEs", Environment and Planning C: Government and Policy, Vol. 29, pp. 641-658.

Preuss, L. (2007), "Buying into our future: sustainability initiatives in local government procurement", Business Strategy and the Environment, Vol. 16 No. 5, pp. 354-365.

Preuss, L. (2009), "Addressing sustainable development through public procurement: The case of local government”, Supply Chain Management: An International Journal, Vol. 14 No. 3, pp. 213-223.

Rajagopal, S. and Bernard, K.N. (1993), "Globalization of the procurement process", Marketing Intelligence \& Planning, Vol. 11 No. 7, pp. 44-56.

Reck, R.F. and Long, B.G. (1988), "Purchasing: A competitive weapon", Journal of Purchasing and Materials Management, Vol. 24 No. 3, pp. 2-8.

Roberts, J.H. (2005), "Defensive marketing: how a strong incumbent can protect its position”, Harvard Business Review, Vol. 83 No. 11, pp. 150-157.

Sanderson, I. (2006), “Complexity, 'practical rationality' and evidence-based policy making”, Policy \& Politics, Vol. 34 No. 1, pp. 115-132.

Saunders, M., Lewis, P. and Thornhill, A. (2009), Research Methods for Business Students, Pearson, London.

Schapper, P.R., Malta, J.V. and Gilbert, D.L. (2006), "An analytical framework for the management and reform of public procurement", Journal of Public Procurement, Vol. 6 Nos 1/2, pp. 1-26.

Snider, K. and Rendon, R. (2008), "Public procurement policy: Implications for theory and practice”, Journal of Public Procurement, Vol. 8 No. 3, pp. 310-333.

Syson, R. (1992), Improve Purchase Performance, Pitman, London.

Telles, P. (2012), "Low value procurement and transparency: squaring the circle", Proceedings of the 5th International Public Procurement Conference, 7 August, Seattle.

Thai, K.V. (2001), "Public procurement re-examined", Journal of Public Procurement, Vol. 1 No. 1, pp. $9-50$.

Uyarra, E. and Flanagan, K. (2010), "Understanding the innovation impacts of public procurement”, European Planning Studies, Vol. 18 No. 1, pp. 123-145.

Yin, R.K. (2008), Case Study Research: Design and Methods, Sage, Thousand Oaks, CA.

\section{Corresponding author}

David Mark McKevitt can be contacted at: david.mckevitt@dcu.ie

To purchase reprints of this article please e-mail: reprints@emeraldinsight.com Or visit our web site for further details: www.emeraldinsight.com/reprints 